\title{
GIANT TEMPEH FESTIVAL: BETWEEN SUBJECT AND GIVEN SUBJECT (A STUDY OF GIANT TEMPEH FESTIVAL IN TLOGOREJO DISTRICT BUMIAJI VILLAGE BATU CITY IN SLAVOJ ZIZEK PERSPECTIVE ABOUT SUBJECT IDENTITY)
}

\author{
Muhammad hayat, MA \\ Lecturer of Sociology Program Faculty of Social and Political Science \\ Muhammadiyah University of Malang)
}

\begin{abstract}
This research entitled Giant Tempeh Festival: Between subject and given subject was done in Tlogorejo district Bumiaji village, Batu City. "Subject" or term "subject awareness" means Tlogorejo Society grow and develop in their awareness of the power of values which they have produced so far. Meanwhile, term "given subject" means that there is intervention of other values which are more dominant to influence society's daily attitude. Those other values tend to eliminate society's original values.

This research uses qualitative approach with descrptive model. It employs the theory of subject by Slavoj Zizek. This theory point out that subject grows and develops in the daily awareness of society.

The result of this research shows that subject emerges in local values which are represented as manifestation of corn rice as embeddedness. There is embeddedness whice can unite society in their daily attitude based on attitude norms in their knowledge. Further more, Giant Tempeh Festival is also process of learning about atificial thing. It means festival is a sign of image of something with material sense which slowly interferes and eliminates the local awareness on local knowledge. Finally the subject begins to move to something which is so artificial.
\end{abstract}

\section{A. Background}

Social group is not a frozen identity. The group existsand understood as an identity when connected to other social groups either as almost similar identity or as different one. It also happens in Tlogorejo district. As one of administrative regions in Bumiaji Village Batu City, Tlogorejo district is the most isolated district. The place which is at the end implies how isolated this district is from interaction with other regions. This condition eventually describes how close natural identities as the metaphor image of this district. Punden is respect manifestation to the one who gives space rejo (rejo is understood as abundant material blessing). Wingit places becomes sign of past image on mith descriptionrelated to the history of Tlogorejo district. Honourable stratification of dukun as important part in status classification is often in the front line related to mystic things considered as parts of the past which are still embedded in 
society values and norms. Authentic tegalan which still implies care for nature as blessing has given image on nature which seems to be spatial that has a power of enforcement to all population to respect and obey nature rules as mai "attitude" so that district streets can be mystic spaces which have to be treated subjectively.

Culture as action basis can also record clearly how nature becomes knowledge basis of society when they try to create various special art in Tlogorejo district. Barongsai, oe of chinese art, has been in dialog honestly based on the "force" of dukun (clever man) who is responsible in barongsai through ubo rampai of Tlogorejo nature believed as taken for granted by the pioneer of Tlogorejo district. Barongsai is a condition of dialog between what is seen clearly and what is implied. It gives image of the balance which is available in this life. Therefore, the phenomenon of the implied reflected by the beautiful gesture of dancer who tries to express about "liyan" is basically the contemplation of heart which should be kept in daily behaviour of the nature and the implied. In this context, barongsai describes macro cosmos and micro cosmos clearly. In javanese cosmologi it is called jagad cilik (micro cosmos) and jagad gede (macro cosmos).

Another culture describing geographical centrism or nature as orientation of Tlogorejo society norm has been clearly recorded in the culture of pencak silat (martial art) manunggaling ati. This traditional art which his orientation on how to nmanage feeling and soul seems to give a message on contemplation which should balance society daily behaviour. Nature which is managed through population hard work in living should be balanced with the ability to place "feeling" in human interaction. The condition of soul must be an important entry point which must be kept allthe time. Finally, that balance will make all aspects in Tlogorejo district unite in one balance.

Reality in deep natural sense reflected through daily life of Tlogorejo society has made the policy maker determine Tlogorejo district as priority of tourism district in Bumiaji Village. The condition of nature with topography of hill and tegalan sorrounded by big trees which are in a good care has been an added value to tourism with local accentuation basis. Space which is significantly separated from other districts has given a colour of how firm and deep the identity of Tlogorejo society is . In the early of 2018, the policy maker, in the case, the authority af regency and Bumiaji Village agree to determine Tlogorejo district as tourism district in Bumiaji Vaillage. As a tourism district or tourism destination, Tlogorejo must have particular tourism icon indicating Tlogorejo characteristic.

The head of district together with some pioneers and honourable society agree to make corn rice which is routinely eaten by Tlogorejo people, as the tourism icon of Tlogorejo district. The cultural ritual of eating corn rice together is planned to 
be held annually. The event of eating corn rice together has been done for the first time in February 2018, corn rice completed with "jangan pedes" urap-urap consisting of lettuce, cassava leaf, pepaya leaf, kenikir leaf, lamtoro and mendol is a special food in Tlogorejo to remind society of how corn rice can firm both economic and social identity of society. Banana leaf as plate is a firm reflection of how local accentuation his found as place to grow.

The culture of eating corn rice which is expected as the tourism icon of Tlogorejo district has found its space to grow when Sociology Program Of Faculty of Social and Political Science Muhammadiyah University of Malang through its Sociology Camp Program tried to make an activity which can characterize the place where the camp was held. Based on the meeting with the Head of district it is found that cultural activity of eating corn rice is interested to be taken as an icon. Then the steering committee of students association in Sociology Camp suggest to held a program called Giant Tempeh Festivalin order to familiarize the icon of eating corn rice together. And the idea was accepted by Tlogorejo district population.

The Giant Tempeh Festival was held on Saturday, October 20, 2018 along the man street of Tlogorejo district.The Giant Tempeh Festival brings past image and ties to the present condition in order to give a space for the past to accentuate. Is it right that this festive has been able to be the part of the groit to eliminatewth of subject awareness (Slavoj Zizek idea about awareness in social group identity as the analysis tool). Tempeh is expected to crystallize the memory on past artefact as possible puzzle to be arranged and felt as law of repetition. Another question isn "Is it possible that the festive is eye catching and crispy image of the real sign which is beautifully seen but in fact it is actually fire. The festival is society terminology in the face of Industrial Revolution 4.0 which gives more price on outer appearance as real attitude. Tempeh is a word tied to the outer meaning of festival isn't it to eliminate feeling and soul of tempeh which should be signed and formed as subject. In this perspective, is there a subject in Giant Tempeh festival or is it just a given subject ( given subject is Slavoj Zizek idea about social group with lost or weakened identity). There two crucial ambicalence are important points in the reseach on Giant Tempeh Festival held in Tlogorejo district

\section{B. Research Question}

Is Giant Tempeh Festival the identity of subject or a given subject?

\section{Research Purpose}

To know further about Giant Tempeh Festival as the identity of subject or given subject 


\section{Research Significance}

\section{D.1. Theoretical Significance}

The give encouragement or criticism to Slavoj Zizek theory about subject.

\section{D.2. Parctical Significance}

\section{D.2.1. For the Policy Maker}

This research is expected as a valuable input for the policy maker so that every policy can be based on local knowledge grown in society, especially society with high homogeneity level.

\section{D.2.2. For Study Program}

This research is expected to be able to serve as a reference for other researchers in a similar theme particularly the ones using subject theory from Slavoj Zizek.

\section{E. Research Methodology}

This research uses qualitative approach with descriptive model. As a study which places after postmo as a perspective, against methods as a basis for tool analysis to see an explanation can be understood as reasonable or not. Wilhelm Dilthey, the main scientist whose idea is about against methods has described that whatever method to be used, as long as it can explain something as "reasonable" it means that method can be comprehensivelly used as analysis tool.

Based on the statement by Wilhelm Dilthey, recording the process of Giant Tempeh Festival as an event on the firmness of identity of subject or given subject has been its point of view. By recording data throug observation on the "event" will show the subject ambivalence clearly. Recording data of documentation about the "event" will enable us to identity comprehensively about whether it is subject or given subject. Recording data through interview will make us find the fill picture or chains on the firmness of either subject or given subject.

Reasonable point of data analisys with against methods basis can be seen from inetrsection amongabservation data, interview and documentation. Therefore the priority scale in collecting data in participatoryspace must be obligatory. In participatory, it will be easy for us to determine whether the data can be complementary or not. Therefore, in participatory there must be an awareness on "field is rational accentuation of a researcher". Starting from identification map of data collection like that, the arena of being together while talking about anything with research subject has become inherent part of this research. It is important to be deep informal rooms to catch honest and natural messages of knowledge which is expressed in a familiar and subjective way. At this point, the honest and natural space flows and happens as condition as what it is. The researcher has experienced the step for a few times through togetherness in jokes wrapped by focused statements from some important figures in Tlogorejo district as the research subject, such as Haryonoas the head of 
district, Hasyim as the man with more talent (clever man) and Sarmidi who is considered as the man with more capability compared to other local people.

The data collection is also done by becoming a part of a close interaction with district women in PKK. This process is important to learn about "being and talking together" about kinds of food or ubo rampe which will be served in Giant Tempeh Festival. The process of reasonable data also recorded when Tlogorejo population and people from Sociology Program of Faculty of Social and Political Science Muhammadiyah University of Malang unite in the festive situation of gym together before the festival begins. Informality which becomes interaction subjectivity brings researcher to the image about ambivalence between subject and given subject. To be part of serious or informal talk with the steering commitee and university students is also an important part of this reseacrh. The idea of Giant Tempeh Festival is coming from them. Starting from various research subjects with their own accentuation, selecting and identifiying as a basis of reseanable explanation which is expected to be described and framed comprehensively.

\section{F. Theoretical Framework}

Subject in perspective of Slavoj Zizek is understood as awareness on local environment as basic knowledge. This condition guides subject in their attitude based on their ability to understand nature. Locak knowledge becomes the main chain of how a cultural product can emerge and then can be derived in daily attitude. In culture embedded what is understood by subject. It is condition which finally can make subject thing to have space to build relationship continuously or keep in touch with environment.

In subject awareness, human don't lose their selves but they even firm up themselves. Culture as the product of locality has become "sign or symbol" of self who keep firm and firmed up. In a firm self, it is not about controlling self but aware self. Therefore, although humans reproduce "the real" to become "the symbolic", the reproduction remains a part of self awareness to strengthen local knowledge. This condition shows that in reproducing something, humans will produce awareness as "human". Human is thing in praxis sense. In praxis humans produce self which relate to thing as tool to produce culture not only as self interest, but in order to strengthen self awareness. For example: eating corn rice as tradition. This phrase is a form of social group commitment to give respect space to "corn plant" which is considered to be able to give protection and enforcement on economic intitution. Therefore corn plant is finally placed as "thing" which has to be reproduced from "the Real" to be "the Symbolic".

The event to be "the Symbolic" is a form of firmness of human awareness of "local knowledge" and not a sign of the presence as merely product, but a sign of 
the presence as "thing" which gives space for human to process in the awareness of "local" or "nature". Local or nature is finally about experience to be aware of self. Self who is aware becomes momentum to move ratio not only "rationalitation" but "subjectification". Basically rasionalitation whic is moved by subjectification is a process of ratio which is moved not as count by numbers but ratio in "qualitative" awareness. This is awareness, where humans are in process in interaction space, they accentuate response with empathy and sympathy. In empathy, humans understand local or nature as the way to understand definition. Definition is not a logic about controlling self, but self who gives space for the defined in order to be respected as something real. Empathy moves self awareness to give sympathy. This phase gives ease for humans to be aware that "thing" which has given the benefit is symbolization of something. This is the phase where "the Real" is moved into "the Symbolic". Symbolic is not something eliminating self as subject, when thing has become "the Symbolic". In fact, the production of the sign or symbol has created a symbol of self awareness as subject.

If we put that concept in research context, it shows that corn plant becomes tradition of eating corn rice. The tradition is symbol reproduction in order to firm up humans awareness as humans. This is where "human" means. In that tradition, human is recorded through relation (silaturahmi), brotherhood (guyub rukun), ann tolerance (tepo seliro). Vocabularies in local accentuation have given space for self to keep in process in subject awareness. In this context, subject is process of self awareness to exist in the learning process so that there is a space to be aware of. Subject is not self who is directly aware of, but subject is vacant self who is moving to be aware of. According to Slavoj Zizek in subject redefinition in culture, it synthesizes as vacant cogito. Subject is not a part taken from universe, but it is hole in universe. It is open hole which always needs to be filled by others. That kind of understanding will not make subject exhausted. As vacant space, subject can always be filled by anybody who is offered by a process namely culture (Thomas Kristiatmo, page $90-91$ )

Statement of Slavoj Zizek shows that a vacant subject can fill in themselves based on knowledge given by the universe. That knowledge has become their ways in building subject awareness. In that process, humans move themselves through relation process (silaturahmi) with environment as the way to produce awareness of knowledge. This is where humans build their awareness. An aware self is self who can manifest their knowledge as subject manifestation. An aware subject is subject which is not influenced by product of learning process about "knowledge" but self who understands that recorded knowledge in their created product is subject ability to harmonize between process as an awareness and ratio as possibility wich creates idea. This 
is where idea finally becomes a concept tied by process of self awareness which intensely relates to knowledge. The word 'intense' refers to statement about "praxis" self which equivalently unites awareness and ratio. This is where humans build vacant space with self who has awareness. Finally subject moves themselves not only reproducing but also protecting, taking care and respecting. In this phase, humans will not treat what is created merely as "tool" which can be lost when humans are bored and have found another produt. The important base of subject awareness is when there is statement about introspective self. Subject grows and fill the vacant in the process of balancing "human" and "logic"

Industrial reality which refers to "thing" is only material which places humans not as subject but as subject which can not accentuate their subject being. That statement refers to in ability of humans to place themselves as subject but they become object of their own. In this phase, humans can not show their existence. Human are only remnants of parts which are kept ruined by artificial product which should be controlled but in fact the artificial product has contolled humans. Slavoj Zizek synthesizes it is given subject.

When the tradition of eating corn rice is manifested as "icon" of Torongrejo district to attract tourists, actually it is event which moves or changes the pagant to be the profand. In pagant, we find self awareness as subject who keeps related to local knowledge in the cultural product which records subject in their awareness of learning process. It is a process of placing self in both evaluation and contemplation area. Meanwhile, in profand, the tradition of eating corn rice is only tool to satisfy subject. That event doos not place subject in their awareness but it makes subject trapped in fake. Corn rice which becomes etalase in Torongrejo society will not be served as manifestation, but only as a sign of "desire". As desire, it will be filled by humans ability to control, not humans ability to contemplate. This is image of humans who lose subject. In tradition of eating rice served in luxurious and catchy etalase, humans are only physical image which can not contemplate. Corn rice tastes so crispy and attractive in eye catching etalase, but in fact is just the beginning of losing self.

\section{G. Data Analisys}

Giant Tempeh Festival held on Saturday, 20 October 2018 is an event which ties society in the ties "festival" and "slametan". Festival refers to artificially sign intentionally served as society way in understanding and interpreting environment often ended in "desire" on materialism of space and body. Meanwhile slametan refers to religious sign to respect space as the ties of body as the soul. There is body ambivalence which exists to move in cheerful body but actually destroyed. Zizek Syntesyzes this as given subject or contemplative body in words 
about soul which is aware of himself. Self in vacant which keeps questioning about awareness of self as soul Zizek syntesyzes this as subject.

Based on above analysis, the event of Giant Tempeh Festival has actually described the reality of the firmness on awareness of subject and also has weakened the awareness of subject or given subject. The followings are field findings which move in the reality of subject and given subject.

\section{G.1. The culture of eating corn rice as identity of subject and given subject of Tlogorejo society.}

The idea on Giant Tempeh Festival can not be separated from tradition of eating corn rice which is intentionally reintroduced in Tlogorejo district. It is a form of obedience on the government policy on the decision to make Tlogorejo district as tourism district which must have muse or icon expected to be point of view wich can help local people economically. A study about that has given an important statement about the degradation of local subject (in this case, the identity of Tlogorejo district)

\section{G.1.1. The Culture of Eating Corn Rice as Given Subject}

\section{The Intervention of Policy Maker}

Policy maker in the "subject" constelation of Slavoj Zizek can be understood as a form of subject awareness interaction. Bumiaji regency as the deklegation of city government has an interest to make Bumiaji as tourism spatial. Bumiaji Village is expected to be able to make important dream of policy maker come true. Tourism idea eventually beautifully expressed in tag line "amazing Bumiaji". Spatial finally ends in the price of material. Tlogorejo district becomes important basis of that tourism movement. The culture of eating corn rice which is served as the front gate for people to think about "amazing Bumiaji" has become puzzle which must move and be shown for the interest of the "etalase". The culture of eating corn rice which was first introduced in February 2018 because of the coming guests from Jakarta is finally limited as a frame which is essentially not moving. Guests as a sign of relationship is only in "etalase meaning". The guests where then deep in joy to taste corn rice with all variety of ubo rampe.

Corn rice in that eye catching wrapping has been shown up in body emotionally which only tasted as desire. The host, in this case district officials and society begin to join the relationship in greeting and joy about etalase. The one which emerges is not about local self, but self which moves in the attitude of "guests". The guests may talk about amazing things. For example: This is called authentic. This authentic this must be introduced to more people in order to have opportunity to move in a bigger space. But since it has to be in a more various space, the serving must be more beautiful. Maybe the banana leaf (as plate) can be added by glowing ornaments to make it more luxurious. 
That statement may seem to be amazing and nice, but in After Postmo Perspective, taht is the beginning sign of weakening subject awareness. Local subject will be brought in a sign of body thirsty of material. In such body, no subject is vacant/ empty. The one that exists is subject as a result of socialization an $\backslash \mathrm{d}$ finally internalized as "capital".

The term vacant or empty subject in Zizek idea becomes very important because it is the starting point to express important philosopical questions related to awareness asking about environment . In vacant idea, subject has awareness to change "the symbolic" into "the real". When culture of eating corn rice is disturbed by the intervention of " capital sign", at the end, the one which exists is "the symbolic" becoming frozen sign with the main manifestation just as desire. The phrase " maybe the banana leaf can be added by glowing ornaments to make it more luxurious" is the manifestation of "the symbolic". If it becomes new society awareness, other original signs as authentic identity of Tlogorejo district, sooner or later will be changed into "the symbolic". The next step which we will see is a might be that Tlogorejo district is "etalase" which exists only as desire but not as soul. Such condition shows that the interventionof policy maker often only shows the body as uniform, not body which has a soul. According to a book of Postmodernism in Poem track by Muhammad Hayat page 39 support the idea of desire of body which restricts the subject as something lost in the wrapping of space crispy and eye catching.

Mall is a fact about space domination

All are glamours without the break about the corner

No edge, though lost in restriction

Restriction is not visible but fatamorgana

No oasis or vacant

All are obedient in restriction which manifest not is restriction

All are etalase definitively

Only exists in manifestation

Visible, no excuse

Not moving, but into the force of "the thirsty"

The above part of poem based on David Harvey idea on "Time Space Compression" can be taken as analogy based on the instruction of the policy maker to syntesize the icon in Tlogorejo district showin $\mathrm{g}$ that the culture of eating corn rice only serves as "the symbolic". The next movement is Tlogorejo district will only be understood as a sign of symbol, and not the essence. Symbol is only artificial. It is "thing" which destroys local knowledge to facilitate the existence of society which begin to lose their memory of "the past".

\section{Helping Local People Economically}

Helping local people economically is the phrase of desire on capital oriented. Corn rice becomes symbol of symbolic human. In this context, policy maker often only legitimate through rules or controls. In rules, the entire social group are moved in 
order to be the uniform. In fact, rules are often limited to piece of paper discussed conceptually without knowing about the real condition in the field/real word. Participatory contextualization never becomes the main chain. At the end, rules and only a pity which remains Tlogorejo district as puzzle which is getting difficult to rearrange. In the eyes of capital, group potential eventuallybroken into individuals interpreting independently on how they must plan, do and evaluate economic term. The condition is unsufficient to move together as a power. Jusat like what is said By Haryono:

After Tlogorejo district is stated as tourism district, we are asked to create icon and we must do it ourselves. It is hard. How to plan, do, evaluate and follow up."

The above statementshows that government only want to make "the symbolic" as the action of helping society to be economically prosperous. The unclear description enables image on economic action done by society to be just illusion which tend to destroy society authenticity. When society take action, it is not as a collective form but individual interpretation about self which synthesizes economic condition.

Guidance has never been thought by policy maker to be done. Society as a collective unity experience stagnant step in interpreting space. Meanwhile "the policy maker" has begun to synthesize "the symbolic" in another space through the power of legitimate rules. In fact, participatory guidance is important basis of how interpretation of space constucted by government is possible to be redefined when in process together with society. There is a discourse about space as the result of recognizing, trial and error in the field/real world, eventually evaluation is "relationship" of thought about conceptual identification recorded clearly in the field finding.

Guidance enables dialog between society and policy maker. It moves in horizontal relation where "space" in Tlogorejo district is place to learn together, especially to measure how effective the idea about making the culture of eating corn rice as identity. Trial and error in guidance has finally become knowledge basis moved based on field findings to respect local as the attitude basis. At the end, space through guidance, space can find the identity of su〉 bject. In subject, questioning something to be answered in empirical reality has basically been evaluating the vacant in subject. The vacant subject in Zizek terminology is subject who able to question and find something as "the real". "The real" is identity which exists and is built by the social group. It is not something which intentionally exists only as "the symbolic".

\section{G.1.2. The Culture of Eating Corn Rice as Subject}

The history of Tlogorejo society can not be separated from corn rice as daily staple food. It shows that Tlogorejo society have placed corn rice as attitude of their economic 
culture. That condition can not be separated from local topography which is suitable for corn plantation. Tegalan with hill topography and some flat topography enable corn to grow well. By recognizing themselves to have corn as staple food, Tlogorejo society are aware that corn is their economic identity. If they neglect this identity, they will suffer from significant effect of economic damage. It is like what is said by Haryono:

"The beginning corn is the staple food of the society here, is suitable with land topography which is suitabkle for planting corn. All for us eat corn from rich people to ordinary people."

The above statement clearly describes the society awareness on nature as the manifestation of life especially the economic spirit. That awareness of nature as attitude will eventually give. The balance of macro cosmos and micro cosmos. As a part of nature which must take care of nature, nature must be treated as what nature wants. When nature with economic condition describing how adaptive corn with nature as the basic staple food, the will apreciate through real actions. It is the condition which at the end creates subject awareness on the real. Referring to Slavoj Zizek idea on subject awareness which priorities the attitude of "the real". The corn phenomenon as the knowledge basis economically shows that they understand "the real" as important in the space of "function". It is was Zizek called as the ability of social group to firm themselves based on the local knowledge growing the environtmen. Finally "environment" is understood as the manifestation of life. In this context, the culture of eating corn rice has firmed nature culture as a way of social group in understanding themselves as subject. Subject which aware of "soul and physic" which must move as the balance of life. In physic tied by corn rice as social fact, human balance body to take care of nature for the sake of balance. Meanwhile "soul" is a process of physic which is aware that in attitude, the balance between macro cosmos and micro cosmos is daily ritual which must stay in the self of each of Tlogorejo society.

The balance of jagad cilik and jagad gede in the culture of eating corn rice is clearly recorded starting from planting phase to corn ready to serve as daily staple food. The process of planting to harvesting takes about 3,5 months. During the process, society take care of corn plant through 2 important phases namely the phase of planting seed to approaching corn harvesting around 3 months. Taking care of plant through making land fertile is important basis to get maximum quality of corn. In 2 months, corn plantation has become "social room" for society. Almost most of the day is spend in corn plantation. The condition enables the happening of society legitimate process with corn plantation as the "main space". That spatial finally records subjective relations in the description of economic attitude. That together space has become informal media 
to firm the subjectivity. Thought and identity of group are built as the consequence of the close space. In that space, finally they sociologically move them through a process in intimate or close space. Space in sociology interpretation has given redefined place about social relation.

That is condition which eventually ties them in one unity of social group collectively. Through subjective process, economic attitude with "corn" as the entry point firmsimportant awarenesson economic legitimate. The ending is awareness on corn as common "dignity" which must be kept by them. Nature as environmental knowledge moves them in local awareness. This is the condition which firms the subject awareness. Finally, corn plantation as mainstream view is clearly recorded from every tegalan or society gardens/plantation.

Harvesting phase becomes important phase to fully describe a full understanding of Tlogorejo society as subject. There are 2 forms of treating corn rice after harvesting namely:

\section{Diombyoki}

Diombyoki is process after harvesting corn to be tied. After all corns are harvested and tied in some ties, they take them home. Those wet corns will be dried in the condition of being wrapped by corn skin to protect the corn. After corns are dry, they are usually put in the kitchen and taken whenever necessary. Corn with the skin outside will be in good condition for quite a long time. It is like what is stated by Haryono:

"After being dried, corn will be kept in the kitchen. Kitchen has a warm air so corn can be in a good condition for quite a long time. We just take whenever necessary in order to be cooked."

The above statement shows that environmental knowledge is the society main awareness. Native with the balance attitude, has been expressed in a balance dialog by society. Kitchen and corn are image on economic attitude giving space for wise dialog about nature as "the real". When "the real" practiced in daily life, it will be understood as basic building to reflect society norms. When nature through corn as "the real" culture practiced in society daily relation, corn will be manifested as a sign of economic culture which ties society. Corn finally grows as awareness of balance between macro cosmos and micro cosmos. Reality of "physic" and "soul" eventually becomes society knowledge basis. Society grow based on what is said to be daily experience. Awareness of environment is awareness of "the real" not "the symbolic". In Zizek idea, self as "vacant" can accentuate environment as realisation about "the aware one" of environment as the genuine of social group. "vacant" is questioning based on what is called as empirical experience. That experience is recorded and practiced as attitude where "physic" and "soul" are in dialog as a balance unity. Macro cosmos is presented by human as microncosmos by 
placing it as "the real".

Ngombyoki as learning experience about corn as sign of economic value can be presented by Tlogorejo society as obedience form and respect to "the real". Ngombyoki finally is a word which can tie them in a unity of common norms about being efficient, diligent, careful, organized (the sociological interpretation is to respect that being organized is the early basis of creating organization which will eventually be implemented as customs or mores) and togetherness. The awareness basis about "the real" will finally create and firm the subject awareness.

\section{Dicengkorongi}

Dicengkorongi is processwhen the skin of corn which has been harvested will be taken off. After that corn will be brought home ( taken from the outer). Next step is drying. After that keeping the dry corn in gledeg ( wood table with a cup board in the bottom side). Gledeg is made of jack fruit wood taken from tegalan or garden next to the house. Gledeg can keep the corn in a longer time. It is enough to maintain the good quality of corn. Society who have gledeg belong to middle to upper level of society in Tlogorejo.

Dicengkorongi becomes real statement about empirical relaity of certain group in society. The sign is not condition of "the symbolic" to firm the status of the certain group, but more as practice of society economic attitude. "The real" pattern diversivication based on the sign in society status group. At the end, dicengkorongi shows that the growing society will imply to arrangement on status difference. Dicengkorongi becomes practice of "the real" in certain group in Tlogorejo. Process of becoming and firming subject moves entite levelsof society with their own accentuation. But nature as ":the real" remains as main basis of how process of becoming subject is developed by society.

\section{G.2. The decision to make Tlogorejo as} tourism district is the early phase of explaining given subject

In sociology interpretation, tourism epistemologically cannot be separated from significant change from social space into material space. The next form is the emergence of tourism vocabulary as knowledge basis in understanding tourism. Realkity describes signing and to moving economic potential which is packed in "beauty", "crispy" and "eye catching". Finally the potential moves economic circulation in society so that they will be significantly more prosperous. However, worrying oppositation happens in the society which make society lose the environment knowledge basis. It is replaced by artificial things. The local sense only as a beautiful etalase.

The decision make Tlogorejo as tourism district seems only to serve authority interest where capital movement must the intensively done to give "sign" of prosperity, welfare and advanced. It is like what is said by Haryono: 
"Tlogorejo is decided as tourism district. It is the desire of officials in village and regency. We must make Tlogorejo interesting as tourism district. The expectation is economic improvement".

The statement shows that the phrase of tourism as industry tries to be socialized by government. Signing eventually becomes crispy image which slowly weakens society genuine. Process is not the sign of what is experienced in understandingf a change, but refers to result as attitude manifestation. Finally "the symbolic" is presented and created to give restriction on "the economy". Learning on space restriction in subject identity isolation, enables "the genuine" experience process from "the real" into "the symbolic". The final product is given subject which is physically awesome but essentially destroyed.

Given subject is unable to question about vacant because given subject is the result of authority control to be controlled one. We find ideology texts which finally creates "the symbolic" in society attitude. Finally society is moved, but restricted to the implementation of authority ideology. Industry sets given subject and starts a new journey about "the past" as amnesia.

\section{G.3. Giant Tempeh Festival is an event to firm up subject and given subject}

Giant Tempeh Festival is a phrase initiated by steering comittee of UMM Sociology Camp and students of HMJ FISIP UMM has become dicotomic face about subject. In Zizek idea, it changes in reality of subject and given subject. Giant Tempeh Festival is an event which ties identity but at the same time gives space to artificial reality to be introduced, firmed up and finally changed into the "identity".

\section{The event of Giant Tempeh Festival is subject awareness}

Giant Tempeh Festival was held in the main street of Tlogorejo district, Bumiaji Village Batu City on Saturday, October 20, 2018. At 4 PM a mountain like in a form of giant tempeh was firmly placed in the central point of Tlogorejo. An hour before, $100 \mathrm{~m}$ from that place, in front of Tlogorejo meeting room, hundreds of people came and gathered to do gymnastics together. The crowd kept moving to meeting room, that phenomenon shows that the formal and informal relation process has happened very well between Sociology Program of Faculty of Social and Political Science Muhammadiyah University of malang and Tlogorejo society. The ties which end up in subjectivity has moved both sides to have a commitment to support any program that will be made.

The reality shows that Giant Tempeh Festival with all activities is an event of trying both sides in at common identity. Just like the Chantal Mouffe term, an After Postmo Scientist, an event is the establishment of awareness of common identity ties. Giant Tempeh Festival is a way of the two social groups to give definition about us. In that 
event, we are related with sign of care, social cohesion and togetherness. This is tradition about subject remembering sign of "the past", to be practiced in the attitude. Giant Tempeh Festival is remembeering "the past" which is still embedded as society values which still stay. Those values experience provocation to be movement when thought of "the past" tries to be made sensitive through Giant Tempeh Festival. When the past as the embedded grows and moved again, it will move as identity in collective attitude. Awareness of the past becomes from of awareness of self of subject. According to Slavoj Zizek, subject is experience of giving learning space as vacant. In vacant every self tries to select and finally vacant is comparative space for reality. Reality of the past which is genuine part of society can give sigb of local power. In the local, ties grow about us which is subjective. This is the past remembered as power. In event, power grow to be considered as the movement together.

At 03.20 PM gymnastic began, a woman became the instructor. Hundreds of people gathering in front of meeting room stood in rows as a beautiful unity. Popular local songs in rhytmic music tried community of Sociology of Faculty of Social and Political Science Muhammadiyah University of Malang and Tlogorejo society in dynamic movement as awareness of gym group. Zizek synthesizes as subject reality tied by an event. In subject recorded by event, all selves consider event as communal ties. Event moving group awareness to be together and move dinamically. Rhytim in gym is dialog about us naturally happens with all of their own accentuations and sensitivity. Some women can follow the instructor movement in elegant way. Some other women cannot elegantly follow the gym, but still confident. They don't think much about beautiful movement. In the condition of common identity, movement is not essential, but soul us common awareness which is important and becomes point of view about selves together. A group of new students have dudden idea. They can hypnotize other gym followers through dynamic movement as if moved by nature. The view shows natural and honest impression.

Gym is the beginning which ties identity, now or past. When the past is awareness of aware subject, attitude will firm up awareness as collective sign. Giant Tempeh Festival is image on awareness of economic institution. It reminds us on society real condition moving as common awareness. In gym, "the real" is about entire who are aware as together. That awareness creates idividual imagination of collective image. In individual image, for example, there is a university student who spontaneously makes different movement but the movement ties collective and emotional memory. In seconds, the group of university students become the part of that movement elaboration. In Zizek idea, that condition is actually statement of actor awareness which can dialog, wildly or directly 
to entire group. The wildness is recorded in movement manifestation to empower feeling to be united in similar movement. Meanwhile, the term, directly, refers to individual ability to be the part of collective system which has been tied by gym as event expressing phrase about statement of group identity awareness. Individual image which becomes group image eventually turns to be face about the embedded self in event awareness. In this phase, Zizek synthesizes aware self as common group building. There is awareness of me/self in which the "accentuation" is me who is aware of becoming part of Tlogorejo society awareness. The next seconds, the beautiful movement and feeling flexibility of all participants in gym is we who move as identity. In that afternoon, iedntity finds its growing space about we/us as locality. The reddened afternoon wrapped by orange sunshine become the witness of kolase identity which expects to keep growing as power.

Gym ends in joyful atmosphere participants are getting more excited to welcome Giant Tempeh Festival. From main lane of Tlogorejo street, Giant Tempeh stood firmly and ready to be brought to the center of festival in front of Tlogorejo meeting room. The Head of Program of Sociology FISIP UMM together with some lecturers and head of Tlogorejo district focusedly stood at the right and left side of the giant tempeh. Hundreds of new students of Sociology FISIP UMM happily lined up at the back of giant tempeh and ready to be part of festival of society collective identity. In the festival, we synthesizes group awareness. Group becomes part of the way we dialog relation pattern. At the end it is not we as sociology people in one side and we as Tlogorejo district in another side. Festival has tied us as common group in togetherness. This is subject who accentuate values in agreement on exchanged values. The exchange has grown feeling about us/we who are aware, not we in negation.

Giant tempeh in a mountain-likeform begins to be brought by hundreds of people firmly lined up accompanied by local song gundul-gundul pacul giving more values on identity. The crowd walked around 150 metres from giant tempeh took its honourable space in front of Tlogorejo meeting room and the excited crowd moved in happy emotion. Referring to Chantal Mouffe on event, where rationale identity moves into irrationale. Therefore, this phase clearly describes our power aware of identity. In identity, it hades itself subjectivelly and moves objective spirit as process of grouo subjectivity. Social group in that space will lead us as subjective awareness. This is we who finally becomes objective the process in Zizek idea can be underlined on phrase self in exists in "self who experiences" and "self who is aware". Self who experiences learning can understand that empirical event is not merely about physical self but thinking self who ends in self who is aware. This last phase grows group emotion leading to common 
awareness (together). This is subject who accentuates event as experience about "self who experiences" and "self who is aware of".

Giant tempeh began to approach festival room. Then MC started to narrate kolase about Tlogorejo history. There is a phase about we which should trace "the past" as "the embedded". The past is phrase about values and norms which should be able to make us aware thet reproduction as taken for granted; not aforism. It must give enough space to local accentuation and local wisdom. Meanwhile aforism is Nietzsche image that history is sign about no power in self. Therefore, history must be lost and destroyed. Zizek idea about subject can grow power when the past is understood as self who experiences and aware. This condition enables us to become identity who is aware of genuine and sensitive on the change. Finally history is manifestation.

Giant tempeh has been exactly in Tlogorejo main street, 50 metres from Tlogorejo meeting room. History of Tlogorejo told by $\mathrm{MC}$ is still in memory about "embededness". Embededness about the past becomes tying phrase about Tlogorejo. It is knowledge tying society with all values and norms. In values, society make them as ideology kept as chip to be the code or sign if how valuable the knowledge that they have. In norms, society act or move themselves based on knowledge which is coming from learning experience together. Knowledge ties the awareness meaning, identity and we who experiences and aware. Embededness is oase about subject growing in our awareness which strengthens locality. That reality is paralel with Zizek idea about subject as the aware. In "awareness" all about self is attitude as nutrition and power. Giant tempeh has firmly stayed next to Tlogorejo meeting room. The next second, all audience stood firmly in contemplative atmosphere.

Hundreds of people stood around giant tempeh in the front and back side. At the back of giant tempeh, there are Tlogorejo senior society, head and lecturers of Sociology of Faculty of Social and Political Science Muhammadiyah University of Malang, steering committee and sociology students singing gundul-gundul pacul. Meanwhile, in front of giant tempeh, Tlogorejo society welcome tempeh by standing in row. Laughs becomes the main frame of entire audience. Corn rice served on banana leaf becomes genuine awareness which can take all audience to event " about us we who grow together with nature". Nature is manifestation. Therefore what is presented by nature is accentuation which must be translated in daily attitude. The next action is ability to derive nature in phrase of economic system through natural products reflected in spesific food in the society. Society understand nature in their mind about "geographical centrism". It is awareness of nature as manifestation of protector, guard and blessing giver. Local knowledge can be mixed from experience to strengthen local 
economic institution. In Zizek idea, subject in vacant will question and make it as action when process or experiencing changes into action. Then process can practice it in the real experience of actor's daily life. Corn rice is sign on economy which is reflected in practice of economic system. Society give firmness through experience with nature. Finally corn rice becomes the way to act in economic system. Corn rice as centralize finally moves other economic signs. Here economic derivation happens big taking what is in the nature as economic experience. This experience tell about creativuty on corn rice as the phrase of causa prima (the cause). Then come derivation about lettuce, cassava leaf, papaya leaf, kenikir, lamtoro as friends to eat corn rice. Derivation of vegetables has tied meaning about centralized corn rice is getting stronger by other food to complete corn rice. Example, hot spicy vegetables (sayur pedas) consisting of tofu, tempe, tomato, coconut milk, chilly. Big and small chilly give image on how nature is knowledge about society awareness. This awareness can move power so the growing institution especially economic and social is original creativity of society. Along with Zizek idea about subject, subject in vacant is subject who questions, experiences and finally moves in order to move the surrounding. Tlogorejo society in the face of corn rice is subject in local awareness which is honest and no pretention.
Corn rice on banana leaf along 50 meters becomes sign about local accentuation. Not to mention complementary ornament like lettucewhich is so attractive with its fresh green colour. Fresh cassava leaf accompanying warm corn rice gives image about local food as desire on nature as a need. Papaya leaf on lettuce shows that balance is very important price in economic system. Weanwhile specific fragrance of kenikir illustrates how arranged local wisdom reflects society face as it is. Lamtoro seed signs nature as blessing giver. Corn rice plus all attributes is society cultural product which manifests in common awareness. When what we see is active subject who keeps moving in the beauty of experiencing and aware. This subject, not given subject. Ation

Haryono, as head of district started festival by telling about a brief history of Tlogorejo. The seriousness of audience in listening becomes mainstream of kolase slametan and strengthens naration about Tlogorejo history. Rachmad K. Dwi susilo, Ph.D as Head of Sociology Program FISIP UMM stated that how the local which is kept and maintained can give extra ordinary power for society economically and socially. Giant Tempeh Festival is the sign of identity which must be introduced and moved so that awareness about we who are aware of nature as knowledge wll keep staying in the self of every Tlogorejo society. Prayer becomes the last ritual before giant tempeh becomes silaturahmi arena for every body there. 
Giant tempeh soon becomes "festival space" for every body there. The circular bottom side of giant tempeh in 1,5 meter diameter is full of corn rice with all attributes like lettuce, cassava leaf, papaya leaf, kenikir and lamtoro. On left and right side of giant tempeh there are various children snacks which attract children attention. Another second festival is full of cheerful faces of Tlogorejo society and community of Sociology of Faculty of Social and Political Science Muhammadiyah University of Malang happily grab the food in giant tempeh. Happiness spreads there. Laughs of people heard when they can get a few food. The movement of horray and showing the food they get is exciting few from new students of Sociology of Faculty of Social and Political Science Muhammadiyah University of Malang. Sour smile can also be seen from audience who still cannot get any food.

Indeed, giant tempeh has become kolase tying audience in communal emotion. There is awareness of authentic right. It is right about we who are together in common identity. Event of getting food is collective manifestation strengthening subject awareness. In that beautiful afternoon, we can see that emotion together is a sign of how valuable collectivity is. Tlogorejo society and new students of Sociology of Faculty of Social and Political Science Muhammadiyah University of Malang have given a sign if the power of identity. It is subject who is aware. It is rooted, not artificial.

The next phase from Giant Tempeh Festival is eating together. Rows of banana leaf with corn rice on it competed with all attributes began to be taled by Tlogorejo society and community of Sociology FISIP UMM. One banana leaf is faled by 3 or 4 people. The next moment, all audience eat together excitedly. The rough texture of lettuce gives another rhytm when entering mouth and quite hard to eat. The hot spicy vegetables did not stop them from eating. In fact, they add more hot spicy vegetables as a past of challenging action. Sweat came all over body. Joy is main kolase hard to stop. Some students tasted the local food for the first time. Strange response camp from those students. When tasting new food. The complex attitude is still an event recording about we as identity. In identity they blend and aware of we who respect native. Identity eventually becomes genuine about local which must respected and kept. At the end we are watching process of Tlogorejo society who experience their encirontment/nature and aware to be practiced as common norms. This is based on Zizek synthesis on subject.

\section{Event of Giant Tempeh Festival is Reality about Given Subject}

Basically event is collective individual identities which move into collective identity. Festival often about industrial characteristic which tend to prioritize attributes which are ey catching, crispy or other attractive sense. Finally giant tempeh is also embedded to industrial vocabulary namely festival which ignores orriginality of tempeh. Festival ignores slametan as a phrase embedded in 
tradition of eating corn rice. In perspective of Beaudrillard, festival is only sign of artificial thing. It is physical sign illustrating human in rows of material desire. That frame eventually restricts human to way understanding nature. In physical experience, the physical is the image giver. This is empirism directing code on numbers capital and material. As the artificial, giant tempeh is full of food in the name "consumption". Tango, coffee mix, oreo, etc are many expressing "we" they are signs which lock you in "uniformity". Code which negates our awareness and changes into we in universalism of economis sign.

Giant Tempeh Festival finally only serves as imagination about virtual world. Humans don't record awareness on slametan as contemplative, but unawareness in dumb festival shown as etalase. Indeed, in giant tempeh only some ornaments are given signs as the cunsumption such as tango, coffee mix, or oreo. However, this is the beginning of we who learn about etalase. Festival as if only understood as sudden event about memory. In fact that is the beginning of weakening legitimacy of slametan as contemplative vocabulary. This is what Zizek said as the beginning of forming subject not as full subject but given subject. The living subject is not as identity awareness but subject who starts to be liyan to nature as "real" knowledge. Afternoon is getting late. The phrase of festival starts to be heard and starts living in the memory og Tlogorejo society. This is subject who begins to learn to live in the influence of given subject.

\section{H. Conclusion}

Giant Tempeh Festival ranges on signs of subject and given subject. Subject is firmed up in local reality through manifestation of corn rice as sign on embeddedness. There is embeddedness which can firm up society to act based on nature norms. Meanwhile, Giant Tempeh Festival is also a learning process about the artificial festival is physical image which slowly eliminates local awareness as nature knowledge. Finally subject begins to be moved in knowledge about festival as the universal. Slowly there is a change in understanding we as subject who is aware into we as given subject.

\section{Reference}

Audun Mortensen (ed), Mati Ketawa Cara Slavoj Zizek, 2016, Marjin Kiri, Tangerang

Donny Gahral Adian, Setelah Marxisme, 2011, Koekoesan, Jakarta

Muhammad Hayat, Postmodern dalam Jejak Puisi, 2014, Gunung Samudra, Malang Muchamad Zaenal Arifin, Metateori Redefinisi Subjek Slavoj Zizek, 2017, Jalan Baru, Yogyakarta

R. Setiawan, Zizek, Subjek, dan Sastra, 2018, Jalan Baru, Yogyakarta

Robertus Robet, manusia Politik, 2010, Marjin Kiri, Tangerang

Thomas Kristiatmo, Redefinis Subjek dalam Kebudayaan, 2010, Jalasutra, Yogyakarta 